\title{
Differentiation Services and Customer Value that Affects Customer Satisfaction and Customer Loyalty PT. Samudra Jaya Sakti
}

\author{
Yusuf Suhardi*, Zulkarnaini Zulkarnaini, Anisa Nanda \\ Novita \\ Department of Management \\ Sekolah Tinggi Ilmu Ekonomi Indonesia \\ Jakarta, Indonesia \\ *yusuf_suhardi@stei.ac.id
}

\author{
Arya Darmawan \\ Department of Accounting \\ Sekolah Tinggi Ilmu Ekonomi Indonesia \\ Jakarta, Indonesia \\ arya_darmawan@stei.ac.id
}

\begin{abstract}
Research aims to determine the influence of service differentiation and customer value to customer satisfaction and customer loyalty services of freight forwarding at PT. Samudra Jaya Sakti. Independent variables differentiation services and customer values that affect the analysis of dependent variables is customer satisfaction and loyalty customers PT. Samudra Jaya Sakti. The population number is large and unknown, so the sampling in this study used MoE as much as 96.4 respondents rounded 100 with the method of analysis used is Partial Least Square (PLS). The results of this study indicate that the differentiation of services has no significant effect on customer satisfaction, Customer Value is significant impact on customer satisfaction, differentiation of services significantly affect customer loyalty, Customer Value has significant effect on customer loyalty, and customer satisfaction has significant effect on customers ' loyalty. As well as the indirect influence between the variable differentiation of services to customer loyalty through customer satisfaction influential insignificant because it has (indirect effect, while indirect influence between the variable customer value Customer loyalty through significant customer satisfaction because of the indirect effect.
\end{abstract}

Keywords: service differentiation, customer value, customer satisfaction, customer loyalty

\section{INTRODUCTION}

PT SJS (PT. Samudra Jaya Sakti) is one of the freight forwarding business company that stands 2001 provides import export delivery services for cargo of fully charged containers (Full Container Load) and also cargo that charged slightly (Less than Container Load) Shipping by air (air freight), sea freight and land (inland).

Differentiation is defined as the company's effort to create differences among competitors in providing customer satisfaction. Generally differentiation of products will result in consumers satisfied with the product offered. Differentiation is the activity of designing a series of uniqueness that means to distinguish what the company offers with what the competitors offer [1]. The average company will lose its half-consumers in less than five years [1]. However, companies with high loyalty levels of products will lose less than $20 \%$ of their consumers in five years. So that the customer loyalty at this time is more focused on the term of consumers using the product it receives in this regard its benefits.

Consumer satisfaction concerns what consumers Express, while consumer loyalty is related to what consumers do. Therefore, consumer satisfaction parameters are more subjective, more difficult to quantify, and more difficult to measure than consumer loyalty. Customer loyalty can be traced through measures such as the number and continuity of the core customers and values for the core customer (in the form of savings that the core customer gained as a result of quality, and short cycle time). Data for consumer satisfaction and loyalty are equally gained from consumer feedback that can be gathered in a variety of ways that the efficiency levels vary. Therefore, customer satisfaction must be accompanied by customer loyalty. Truly loyal consumers are not only very potential to be word-of mouth advertisers.

Suggests that the factors driving customer loyalty are better captured from the consumer perspective [1]. Loyalty that is proof of consumers have the strength and positive attitude of the company that can ultimately demonstrate the level of loyalty from consumers to a particular brand of goods/services depends on several factors: magnitude The cost of transferring to another brand of goods or services, the presence of the quality, quantity or service of the type of substitute goods or services, the risk of changing the cost of goods and services substitute and change the level of satisfaction gained from the new brand Compared to the previous brand [2]

In addition to the product, the company also has its service. If the product has been transferred, another key to success lies in improving the quality of service [3]. In accordance with the principle of the company prioritizes consumer satisfaction, in placing consumers in the middle of the business activities, the company is expected to always pay attention and give consumers in all activities and programs undertaken. So that consumers are always the first party, eventually become loyal to the change.

Retaining current customers is one of the key success factors to survive in the mature market [4]. PT SJS in 


\section{THEORETICAL FRAMEWORK}

fulfilling the needs and wishes of consumers especially the relation in creating consumer satisfaction, a very important element to be aware of PT SJS is to provide sales service and better after sale service, more efficient and more effectively. Good quality of service then can create a satisfaction and finally the consumer will show its agility so that it can increase the company's profit.

\section{A. Fundamental Problem Formulation}

Based on the background described above, there are several problems in this research, namely:

- How does differentiation of services affect customer satisfaction in PT SJS?

- How does customer value affect customer satisfaction at PT SJS?

- How does differentiation of services affect customer loyalty at PT SJS?

- How does customer value affect customer loyalty at PT SJS?

- How does customer satisfaction affect customer loyalty on PT SJS?

- How does indirect influence the differentiation of services towards customer loyalty through customer satisfaction at PT. SJS?

- How does indirect customer value affect customer loyalty through customer satisfaction at PT. SJS?

\section{B. Objectives of Fundamental Problem Formulation}

In addition to the explanation that has been submitted, the purpose of this research is:

- To know the influence of services differentiation on customer satisfaction in PT. SJS

- To know the effect of customer value on customer satisfaction in PT. SJS

- To Know the influence of service differentiation on customer loyalty in PT. SJS

- To know the influence of customer value on customer loyalty in PT. SJS

- To know the impact of customer satisfaction on customer loyalty in PT. SJS

- To Know the indirect influence of services differentiation towards customer loyalty through customer satisfaction in PT. SJS

- To know the indirect influence of customer value towards customer loyalty through customer satisfaction in PT SJS.

\section{A. Differentiation Services}

Some differentiation services (service differentiation) that can be created by the company as an indicator: ease of ordering (ordering ease), referring to how spilled customer can make a reservation to the company. Delivery, referring to how well the product or service is left to the customer. The submission is speed, accuracy, attention during the delivery process. Buyers often choose a reputable supplier who is in good time delivery. Customer Training (Customer training) refers to the training of customers to use the equipment and sellers precisely and efficiently. Customer consultation (Customer consulting), referring to the data service, information system, and advice provided by the seller to the buyer [5].

\section{B. Customer Value (Customer Value)}

The dimension of value consists of 4 , namely:

- Emotional value, utilities derived from feelings or affective or positive emotions arising from consuming the product.

- Social value, a utility gained from the ability of the product to increase the concept of consumer social self.

- Quality/Performance value, utilities obtained by products such as short-term reduction and long-term costs.

- Price/value of money, utilities derived from the preconception of the expected performance of a product or service [6].

\section{Measuring Customer Satisfaction}

Customer satisfaction is an investment which is essential due to the fact that the process of customer satisfaction often don't generate outcomes in very short-term. Remunerations more often are recognised in the medium or long-run. Various resources should be used in order to understand the requirements of customers [7].

Four models to measure customer satisfaction, among others:

1) Complaints and advice system: Every customeroriented marketer is obliged to provide a widest opportunity for their customers to convey their advice, criticism, opinions, ideas, feedback and brand complaints. The Media used is a suggestion box that is placed Ditempat-tempat strategic (which is easily accessed or often traversed by customers), comment cards (which can be filled directly or sent via email to the company), a dedicated toll-free telephone line, website, blog, fax, mobile number, and others.

2) Ghost/mystery shopping: One method to get a picture of customer satisfaction is to employ a few people ghost shopper to act as a potential customer of the company and competitors. They were asked to report important findings based on their experience of the strengths and weaknesses of the company's products and services versus competitors. 


$$
\begin{aligned}
& \eta=\frac{1,962}{4(0,1) 2} \\
& \eta=96,04
\end{aligned}
$$
interview that is necessary but the monitoring of customer loss rate is also important, where the increase in customer loss rate shows failure of the company in satisfying its customers.

4) Customer satisfaction: Survey generally most of the research on customer satisfaction using survey method, either via phone, post, email, website, or live interview. Through surveys, companies get responses and feedback directly to customers and also give positive signals that the company pays attention to them [8].

\section{Customer Loyalty}

Customer loyalty can be defined as the closest step to the repurchasing behaviour of customers. Customer loyalty has usually been referred to as a consequence of all the experiences that a customer has with a service/product provider [9].

Consumer loyalty makes many benefits for companies like lower price elasticity, lower relationship costs, the possibility of increasing income over time, chance of achievement new customers because of loyal consumers' suggestions, lower sale and promotion efforts etc. [10].

Loyalty here can be measured by 3 indicators, namely:

- Repeat/Repurchase, if the customer needs the goods or services provided by the service provider in question will buy products/services in the company.

- Retention, The customer is not affected to the service offered by the other party.

- Referral, If the product or service is satisfactory, then the customer will inform the other and vice versa if there is dissatisfaction on the service received he will not talk to the other party, but will tell the service is less satisfactory The provider [1].

The more they surpass expectations, the more companies are able to gain customer loyalty, increase their profits and as a result, command convincing market shares [11]. Customer loyalty also depends on customer service. Therefore, customer service can be seen as more than a transformation process that is managed by front office employees and, and if not managed properly, it can lead to dissatisfied customers and brand transfer [12].

\section{METHODS}

\section{A. Population and Sample}

Samples in this research the population used are all regulates at PT. SJS with unascertained customers the number due to the increasing number of customers. Samples are using an unguided sampling technique as follows:

$$
\eta=\frac{\mathrm{Z} 2}{4(\mathrm{MOE}) 2}
$$

\section{B. Data Collection Methods}

Collected both primary and secondary. Primary Data is field research. Also the questionnaire is compiled in the form of a written statement and then disseminated, the secondary Data is done by reading the book literature related to the problem that will be discussed to gain theory and definition.

\section{C. $\quad$ Test Data}

In research at PT. SJS uses data test that is Partial Least Square (PLS). In this study, there are 4 variables, two dependent variables and two independent variables.

\section{RESULTS AND DISCUSSION}

\section{A. Inner Model Analysis}

Inner models (inner relation, structural model, and substantive theory) illustrate the relationship between the latent variables based on the substantive theory. A model fit test is used to determine whether a model is matched with the data. In this model's match test there are 3 test indexes, namely average path coefficients (APC), average R-squared (ARS), Average Varians Inflaction Factors (AVIF) with APC and ARS criteria accepted with the terms P-Value $<0.05$ and AVIF $<5$. Based on the output result (see table 1), it can be noted that:

- $\quad$ Average path coefficient (APC): Based on the output, it can be noted that the APC has an index of 0284 with a P-value of $<0.001$. The index shows the result below 0.05 which means meeting the criteria.

- $\quad$ Average R-Squared (ARS): Based on the output, it can be noted that the ARS has an index of 0410 with a Pvalue of $<0.001$ then the ARS meet the criteria.

- Average Varians Inflaction Factors (AVIF): Based on the output, it can be noted that the AVIF has an index of 1,461 (Acceptable if $<=5$, ideally $<=3.3$ Then the index shows the result below 5 then the AVIF value is accepted.

TABLE I. MODEL FIT INDIES

\begin{tabular}{|l|l|c|}
\hline & \multicolumn{1}{|c|}{ Index } & P-Value \\
\hline APC & $0.284 \quad 0.410$ & $\mathrm{P}<0.001$ \\
\hline ARS & 1.461, acceptable if $<=5$, ideally $<=3.3$ & $\mathrm{P}<0.001$ \\
\hline AVIF & \multicolumn{2}{|c|}{ Source: WarpPLS Output Program } \\
\hline \multicolumn{3}{|c|}{}
\end{tabular}

The results of the $\mathrm{R}^{2} 0.75,0.50$, and 0.25 indicate that the "substantial", "moderate", and "weak" models [7]. 
TABLE II. R-SQUARED CONTRIBUTION

\begin{tabular}{|l|c|c|c|c|}
\hline \multicolumn{1}{|c|}{ Variable } & $\begin{array}{c}\text { Service } \\
\text { Different } \\
\text { iation }\end{array}$ & $\begin{array}{c}\text { Customer } \\
\text { Value }\end{array}$ & $\begin{array}{c}\text { Customer } \\
\text { Satisfaction }\end{array}$ & $\begin{array}{c}\text { Customer } \\
\text { loyalty }\end{array}$ \\
\hline $\begin{array}{l}\text { Customer } \\
\text { Satisfaction }\end{array}$ & 0,002 & 0,484 & & \\
\hline $\begin{array}{l}\text { Customer } \\
\text { loyalty }\end{array}$ & 0,051 & 0,125 & 0,159 & \\
\hline
\end{tabular}

Based on table 2, the $\mathrm{R}^{2}$ value is 0.002 for the difference in service of customer satisfaction. As for the impact of Customer Value on customer satisfaction is to obtain the value of $\mathrm{R}^{2}$ 0484. Then to influence the variables of the differentiation services i.e. for the influence of consumer loyalty gained $\mathrm{R}{ }^{2}$ value of 0051 . The value of customer value towards consumer loyalty is obtaining an $\mathrm{R}^{2}$ value of 0125 . And the last value to influence customer satisfaction towards consumer loyalty is to obtain a $\mathrm{R}^{2}$ value of 0159 .

Besides seeing the value of R-Square, the model was also evaluated by looking at the Q-square relevance for predictive model constructive. Q-Square Measures how well the observation value is generated by the model and also the estimation of its parameters. The size of $\mathrm{Q}^{2}$ has a value with a range of $0<\mathrm{Q}^{2}<1$, where closer to 1 means the model is getting better. The $\mathrm{Q}^{2}$ is equivalent to the total coefficient of determination in path analysis. Value $\mathrm{Q}^{2}>0$ indicates model has relevance predictive, preferably if the value of $\mathrm{Q}^{2} \leq 0$ indicates the model has less relevance.

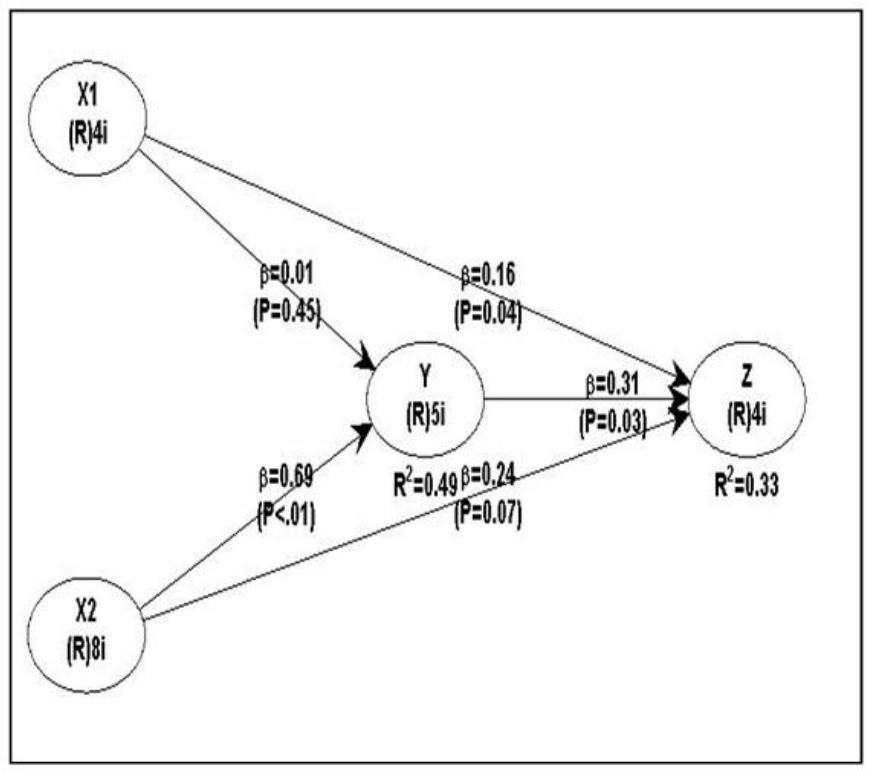

Fig. 1. Data processing results.

\section{B. Hypotheses and Direct and Indirect Impact Analysis}

1) Test Hypothesis 1, differentiation of services (X1) affects consumer satisfaction (Y): Can be seen from Figure 1 that the differentiation of the service influence is not significant to consumer satisfaction has a P-value of 0.45 and negative beta value, because it has a $\mathrm{P}$-value exceeding 0.05 .
That is, in this research the differentiation of services has an insignificant influence on customer satisfaction. Customer satisfaction in PT.SJS cannot be measured from the differentiation of the company's services.

2) Test Hipotesis 2, customer value (X2) affects customer satisfaction $(Y)$ : Customer value to the consumer satisfaction is positively influential and expressed significantly by having a P-value of $<0.1$, which is less than 0.05 , can be seen from Figure 1. This means that the research shows that there is a positive and significant effect on customer's value in the satisfaction of consumers who use the services at PT SJS. The benefits provided by the PT SJS in accordance with what is expected by consumers so that the consumers will be interested to use the services of PT SJS back.

3) Hypothesis Test 3, differentiation of services (X1) affects customer loyalty (Z): Can be seen from Figure 1. That the influence of differentiation of services towards consumer satisfaction is positively influential and expressed significantly because it has a P-Value of 0.04 ie less than in the $<0.05$ meaning the differentiation of services provided by PT. SJS to its customers Consumers to the company.

4) Hypothesis test 4, customer value (X2) has no effect on customer loyalty (Z): Can be seen from Figure 1 that the Customer value has no significant effect on customer loyalty because it has a $\mathrm{P}$-value of 0.07 that is more than $\mathrm{P}>0.05$. That is, in this research the customer value has an insignificant influence on customer loyalty. Customer loyalty at PT SJS cannot be measured from the customer value of the company to the customers themselves.

5) Hypothesis Test 5, customer satisfaction (Y) affects customer loyalty $(Z)$ : It can be seen from figure 1 that consumer satisfaction has significant effect on consumer loyalty because it has a $\mathrm{P}$-value of $<0.03$ which is less than $\mathrm{P}$ $<0.05$. Customer satisfaction can have an effect on measuring the consumer's straightness to a company.

6) The 6th hypothesis test, The influence of the unintentional differentiation of services (X1) towards customer loyalty $(Z)$ through customer satisfaction (Y): Based on the indirect influence (Indirect effect) has a value of $\mathrm{P}=$ 0,455 and direct effect has a value of $\mathrm{P}=0.45$. Its second meaning has a value of $\mathrm{P}$ that is over $\mathrm{P}>0.05$. Meaning indirect influence is not significant then automatic no mediation effect.

7) The hypothesis test, indirect effect of Customer Value $(X 2)$ on customer loyalty $(Z)$ via customer satisfaction $(Y)$ : The Effect of mediation shows the relationship between intervariable exogenous with endogenous through a the of support or mediation, otherwise known as indirect influence (Indirect effect). Indirect effect is not significant then automatic no effect of mediation or indirect influence between customer value towards customer loyalty. Based on figure 1, the indirect influence (Indirect effect) has a value of $\mathrm{P}=0,041$ and direct effect has a value of $P=0.07$. Its second meaning has a value of $\mathrm{P}$ that is over $\mathrm{P}>0.05$. 


\section{REFERENCES}

In this study can be drawn conclusions as follows:

- $\quad$ First pointed out that the differentiation of services has no effect on the customer satisfaction of Freight Forwarding services at PT SJS

- Second show that the customer value positively affects the customer satisfaction of Freight Forwarding services on PT SJS.

- Third shows that the differentiation of services has influence on customer loyalty service of Freight Forwarding at PT SJS.

- $\quad$ Four indicate that the customer value has a significant influence on the customer loyalty service of Freight Forwarding at PT SJS.

- $\quad$ Fifth customer satisfaction affects the customer loyalty service of Freight Forwarding at PT SJS.

- Sixth influence indirect differentiation of services towards customer loyalty through customer satisfaction has no significant effect on PT SJS

- Seventh influence of indirect customer value towards customer loyalty through customer satisfaction significant effect on PT SJS.

[1] P. Kotler and K.K. Lane, Manajemen Pemasaran, 13th ed., Jakarta: Erlangga, 2009.

[2] J. Griffin, Customer Loyalty: Menumbuhkan dan Mempertahankan Kesetiaan Pelanggan. Alih bahasa: Dwi Kartini Yahya dan kawan kawan, Jakarta: Erlangga, 2005.

[3] K. Philip and A.B. Susanto, Manajemen Pemasaran di Indonesia, 2nd ed. Jakarta: Salemba Empat, 2001

[4] O. Leelakulthanit and B. Hongcharu, "Factors that impact customer satisfaction: evidence from the thailand network industry," International Journal Of Management And Marketing Research, vol. 4, no. 2, pp. 67, 2011 .

[5] S.C. Chen, "Customer value and customer loyalty: Is competition a missing link?" Journal of Retailing and Consumer Services, vol. 22, pp. 107-116, 2015.

[6] Kotler and Keller, Manajemen Pemasaran, 12th ed., Jakarta: Erlangga, 2012.

[7] R. Neupane, "The effects of brand image on customer satisfaction and loyalty intention in retail super market chain UK," International Journal of Social Sciences and Management, vol. 2, no. 1, 2015.

[8] T. Fandy, Strategi Pemasaran, Yogyakarta: Andy Offset, 2014.

[9] M.A. Oswald, R. Kesavan, and M. Bernacchi, "Lasting customer loyalty: a total customer experience approach," Journal of Consumer Marketing, 2006.

[10] M. Martinović, "Competitiveness through consumer loyalty: The Influence of Switching Costs," International OFEL Conference on Governance, Management and Entrepreneurship New Business Models and Institutional Entrepreneurs, 2018.

[11] F. Kombo, "Customer satisfaction in the Kenyan banking industry," Journal of International Studies, vol. 8, no. 2, pp. 174-186, 2015.

[12] A. Althonayan, A. Al habib, E. Alrasheedi, G. Alqahtani, and M.A.H. Saleh, "Customer satisfaction and brand switching intention: a study of mobile services in Saudi Arabia," Expert Journal of Marketing, vol. 3, no. 2 , pp. $62-72,2015$. 